\title{
How Trade Wars Affect Exports of the Belt and Road Countries: New Evidence from Dynamic Panel Data Analysis
}

\author{
Ayberk ŞEKER ${ }^{*}$ \\ Oktay Kaan HÜGÜL2
}

DOI: $10.24818 / \mathrm{mer} / 2021.06-07$

\begin{abstract}
Globalization of the world affects the interests of the people continuously in the tendency of being shaped by the integrations geographic factors. By being different from the previous ages, the flow of information allows us today the integration of perception for needs and demands in common sense as a result of global approach, which has been leading to increase in speed of movement of commodities among economies. This increase and practically optimized logistics frameworks drastically reduced the challenge of physical movement of assets among far regions in globe. In our days, a new concept called Belt and Road Initiative (BRI) is being discussed and searching for participant economies to enlarge the volume of trade among Far East and Western Europe. Whereas the process of seeking for participants for BRI, the Trade Wars have been continuing among world's leading economies to sustain domination roles over world trade volume. Considering that the effects of the trade wars between China and the USA on the Belt and Road Initiative have not been examined broadly until today, it is thought that this paper will make important contributions to the literature. As a result of Arellano-Bond (1991) and Arellano-Bover(1995) GMM estimators, it is determined that tariff rates of China is statistically significant and negative on the export of BRI countries whereas tariff rates of the USA does not have a statistically significant effect on these countries. In Addition, Dumitrescu-Hurlin panel causality analyzes demonstrate that there are unidirectional causality relationships from tariff rates of China and USA to exports of the BRI countries. The empirical findings indicate that trade wars have a significant impact on exports of the BRI countries.
\end{abstract}

KEYWORDS: Belt and Road Initiative, Dumitrescu-Hurlin panel causality test, dynamic panel data, export, trade wars.

JEL CLASSIFICATION: $F 10, F 13$ F14.

\section{INTRODUCTION}

Human being has always demanded for achieving unprecedented acquisitions on different fields of life in order to be able to dominate a competitive advantage against the rival communities as an inevitable requirement of sustaining its existence. This individual primary behavior has improved its factual presence to a further level as a result of emerging human communities on diverse locations all over the globe. The rising local groups and the level of awareness resulting in the alteration over consciousness of parties about each other has caused the commencement of a never-ending inevitable contest to govern the vast fields or paths

\footnotetext{
1 * Bursa Technical University, Turkey, ayberk.seker@btu.edu.tr, corresponding author

${ }^{2}$ Bursa Technical University, Turkey, oktaykaanhugul@googlemail.com
} 
binding one to another, more than one another. Whereas, the routes on vast waters and paths through lands became the first squares on the chessboard to be dominated.

In continuation of this competition of groups presenting themselves as nations, began to run strategies to reach both close and far lying sources, which resulted in structuring of very wellknown routes until our day. However, after a long time since the discovery of the latest logistic path achieved, today's China is falling into the agenda with a new concept called "Belt and Road Project" (Zhao, 2020: 319; Chen et al., 2020: 905; Sharma, 2019: 35, Githaiga et al., 2019). A new path lying through ancient lands stands as a unique concept, which will over throne the customary paths being followed to reach the Far East lands (Napang et al., 2019). Additionally, discussed as the "New World Vision of China" or "Search of China for a New Order" by pushing through the bringing about of an emergence of a question in the sense of "if the nerves on Trade wars among East and West are distranding?" (Chen \& Hodzi, 2017).

On the other hand, as it is claimed by monetary and political environment, the strategy of new path project is being evaluated as concept of win-win strategy for Eurasian communities lying on hinterland. Composed of different monetary unions is standing as a enriching possibility of Eurasian economic volume by the elimination traditional exporting countries from usual path via initiatives of China (Kelly et al., 2020: 10). By focusing on the given approach above, the deviation of volumes of trade with the appropriate level of tariffs possibly results in the drifting away of trade volume from western side to east of the globe. Whereas, the righteous emergence of the dilemma about the trade wars would come across with the facts of economy having been sharpened by today's western dominating parties. In case of shifting the core point to the side of Chinese sight, the emerging of domestic and foreign political sovereignty are featuring tasks. The Chinese domestic point of view to insist on implementation of Belt-Road Project also seems, as if having been covering the concerns of expanding its economical hegemony both in Non-Han Dynasty the population dwelling close to borders and to increase its central governmental influence over Chinese hinterland. Beyond the issues can be perceived as the concern of security, the monetary concerns strengthening the precautions against the possible trade wars behind the curtains seem as the basic motivation for the six cores of Chinese Government. Under this perspective the evolution of Silk Road to an economic belt by the deepening of cooperation Eurasian countries by separating under depiction of Economic Corridor as technical modes of transport; Maritime Silk Road and Silk Road Economic Belt. However, the main underlying objective for the cooperation of such a vast containing Project is supported by the concern of breaking the hegemony of the US without taking the reactions of western world in open view. Whereas, as a proving approach of Deng Xiaoping as "Biding Time and Building Capabilities", which structures the thought of Belt and Road Project by emphasizing the need for driving through the sustainable economic improvement and continues stability with the deserved reputation of being the engine of regional economy (Passi et al., 2017).

As a result, under this article it is aimed to touch the open standing subject as; the foreseen level of effects of Belt Road Project and trade wars over countries and the restriction of commercial status. By the clarification of the open standing fields of this concept, the need for continuity of trade wars is planned to be discussed. Whereas, the inevitable and the possible effects and reactions against the Belt-Road Project will be identified as shaping components before the physical commencement of the logistic flow. As one of the most important points of the task, the both domestic and foreign sovereignty concerns of China in the sense of trade wars are going to be taken under the loop to be examined, in order to be able to draw the unseen framework of the project beyond logistic approach. 
This paper aims to reveal the effects of trade wars between China and the USA on exports of Belt Road countries. In this direction, the studies in the literature about trade wars and logistic paths will be evaluated in the second part. In the third part, it is discussed that trade strategies of China and the USA and the development of tariff rates until today. Then, information about the methodology and data is given in line with the econometric analyses of the study and the analysis results are evaluated in the fourth part.

\section{A BRIEF LITERATURE ABOUT THE RELATIVE EVOLUTION OF LOGISTIC PATHS AND TRADE WARS}

Due to the reason of keeping our focus on BRI and its effects of local tariff rates by the influence of trade wars, the historical background basically entails having touched the changing structure of logistics paths through history and emerging competition among parties to dominate far locations with their local products by the provided connection possibilities achieved and tamed logistic roads. The effect and evolution of logistic routes can be considered as the first step to be examined and in progressive part of the paragraph, the rise of trade wars and its counter effects with preferred logistic paths are to be discussed by referring to the future possible co-reaction among BRI and Trade Wars.

The paths of logistics have begun to be formed through the needs of humankind in different locations via pushing desire of reaching together for profit. The main movement under this entrepreneurship took place in afterwards of the emerging of pyramids in vast sands of ancient Egypt, which is considered as if having caused of this trial to the encouragement for the formation of logistic bonds with far locations, in order to be able to supply the construction of monumental pyramids 5000 years ago (Dülfer, 2005).

The following pioneership was going to be led by ancient Greek sailors for military purposes to define the routes for logistic supply for military camps to handle weapons for war, additionally which pushed the reformation of vessels to an upgraded version for new routes requiring bigger and stronger sized vessels. This approach has resulted in the successful journey of Alexander the Great to India as a mass movement of an army to Asia from Eastern Europe (Dülfer, 2005). Whereas, the first determined route for organized logistics among Eastern Europe and India had been drawn in history. Of course, the trials for discovery of different paths to reach further or unknown geographic locations were going to be the core interest of mankind. In addition to all these, not entire trials were taking place in direction from Europe to Asia, there were also initiatives having been taken to introduce exotic far eastern products outside Asian east coasts. As a result of these movements, a counter logistic journey from Chinese region under the reign of the Han Dynasty to the hinterland of Roman Empire had been born for trading of valuable silk of Chinese culture, which was going to be achieving a noble interest. So that, one of the earliest commercial connection for profit can be accepted as the stabilizing of trade over transportation of silk via Eurasian path before 1st Century BC as described by Byzantium historian Procopius in 6th Century BC., the trading of silk from eastern Asia to Europe had never sustained as an unique dimension of commercial relation among parties, more over the more exotic products may attract to interest of wealthy individuals and aristocratic society had been the popular focal elements to be traded to Europe to sign the noble enrichment of monarchs with eastern exotic commodities in society.

As a result of the rising interest, the Silk Road became the most demanded and traveler friendly path to be followed. Of course, Silk Road has never sustained its position as a unique 
road to be driven. The new discoveries and experienced on vast seas were going to be resulting in as the emerging of new alternative routes to Silk Road by partly shifting the volumes of trade to their own lines by binding Eastern Europe, Middle East, Central Asia and Far East via maritime connections through Indian Ocean until 19th Century. These improvements in Eurasian hinterland had initiated a slightly growing and wide spreading occurrence called Trade Wars, the main objective of which is gaining the competitive and dominating advantage over mutually integrating markets. As that has been clearly seen during the 19th century by the acceleration of industrialization in the UK. The dominating direction of economics and flow of money amended its route to industrialized countries. The Nanking Treaty provided a legitimate environment for the UK to take the advantage of trading with low barriers to Chinese market under the reign of the King Dynasty, sustained its hegemony both partly usage of Silk Road and new routes achieved over Indian Ocean until the beginning of 20th Century (Chang, 2007). In case of having a sight from this side of the history, the one of the most famous chases or wars regarding commercial concerns, has begun by the initiation of the UK against China. Surely, the continuous improvements and wide spreading effects of industrialization with increasing interest of people in distant regions regarding the search for convenient products with lower labor expense rates has commenced the shifting of origin of production from west to far eastern countries. This alteration as shifting of advantageous position to far eastern regions is possibly expected to be resulted in a new era of Trade Wars among China and Western Economies.

After a while in the history of economics, the shifting of Chinese economics away from restrictive applications of communist approach, the privatization of state industries in 1997 by Chinese government with the scope of integration to the global economy, gave the first sign of rising of a secondary alternative to the US economy in the World. Finally, China opened its power to the access of the World Financial Market, the export initiative of which has been austerely challenged to be hindered via trials of public groups of U.S, Canada, European Union, New Zealand and Australia. The mentioned unfriendly reaction of western and close regional players against China have been a predictive symptom of a future challenge of a trade war, possibly taking place among leading developed economies later on.

As an inevitable result of global trend of international trade intending on both bringing of parties conceptually over digital platforms and tangibly via physical flow of commodities slightly caused the evolution of existing logistic maps because of increasing demand of delivery of goods from far locations in shorter and more desirable timeline within reasonable freight rate. Whereas, as it has mentioned above at brief development process of logistic routes, the trade wars mostly run over the lower tariff rates, seeking for interested parties both investment and procurement affected the shaping of BRI by the initiative of China. Additionally, the last considerable supporting component in 2018 may prove the sharpening of Trade Wars between China- USA possibly be depicted as the application of new tariffs over the commodities of each other, can be perceived as the new concept of protectionism, has been experienced against liberal trade for decades in the previous century. In spite of tendency of considerable amount of parties to same approach to defend their economies against devastating effects of liberal economy, the China and U.S will be predictably playing the major role on stage. In conclusion, the developing physical connection among far locations to supply the need of each other by focusing on the volume of cash expected to flow to the country of origin, rose the interest of parties to exhibit their own products in different geographies by following the shortest and secure logistic path with the convenient mode of transport. 
As the ages elapsed, the shape of activity has evolved to the form of a challenge, which may award the winner after dominating the market with the most convenient and cheapest good. In such cases, the different methodologies put their contributions on contest by achieving a new trend by either increasing their attractiveness for investment or rising to the stage with the cheapest commodity produced in the market. The first concept requires the decrease in tariff rates for direct foreign investment may perceive the local market as a tax heaven and second can be considered by foreign approach as low value labor power. Both are the competitive instruments to achieve dominating positions in the world market. As it was mentioned that China has been playing with both instruments for a long while by competing with world economics. In afterwards of integration to the open market, the leading position of the US economy has begun to be questioned before a rising mighty Chinese capital. Today with the concept of BRI and the participation of 64 countries under the leadership of China, the flow of capital seems to choose a new path to flow, so that a Trade War among China- USA seems as an inevitable occurrence by today.

\section{THE TARIFF RATES OF ECONOMIES}

Under this part of the article, the commercial strategies of USA and China are being taken under the loop, in order to be able to produce a comparison among each other, which may illuminate the sharpening effects of trade and tariff politics over trade wars in the development process of BRI.

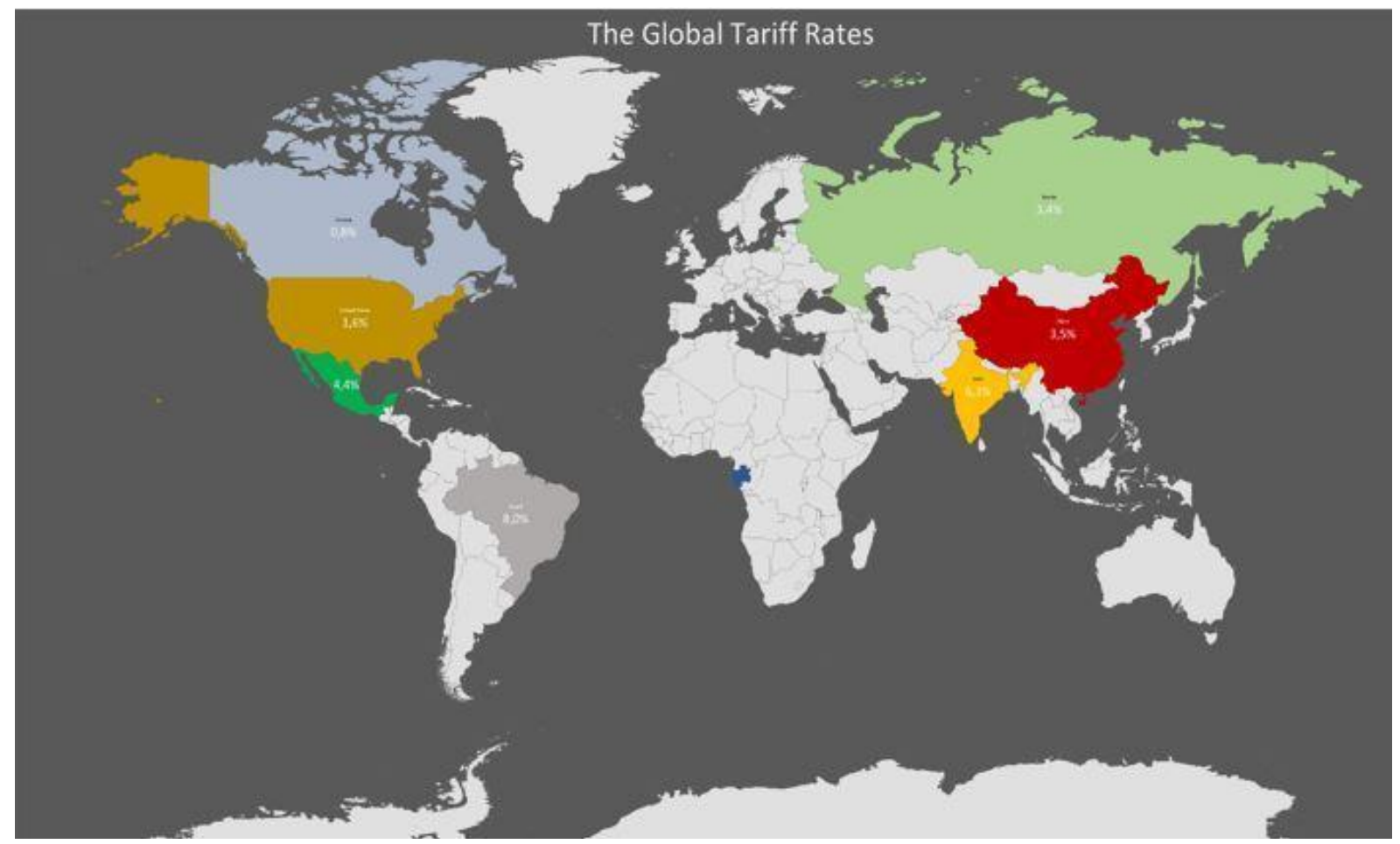

Figure 1. The global tariff rates on map

Source: FORBES, 2018

Tariff rates of China and USA before having an entrance to the tariff rates of these target countries expected to jump into a trade war for a certain victory. Brazil is lying on the map as the highest tax applying country over free trade with the rate of $8 \%$ on average. Of course, the restrictions and barriers over import goods as agricultural products are still the non-resolved hindrances banning the flow of the mentioned class of commodities by causing only on this segment the rise of rates until $13 \%$. If it is required to have a respective order regarding rates 
of tariffs, the second country would be with the average rate of $6,3 \%$, India. The Indian tariff rate was nearly about $30 \%$ until the year of 1991, after the new approach over trade as rationalization of tariff structure, decentralization and liberalization of export-import regime with Special Export Zones (SEZ's), the rates declined the rate of 6,3\% as an actual rate. With the given rate, India is still standing as the highest rate applying country (Singh, 2017). Mexico is standing as the third highest rate dominating country with the rate of $4,4 \%$. Of course, by being different from other countries, the economic precaution and tariff policies of Mexico are being devised according to the counter policies of the US economy being applied over the products supplied from Mexican producers. China as the fourth highest tariff applying country has driven its economy to a radical process of transition to a more liberalizing structure under the communist perspective. The tariff rate is nearly about 3,5\% and standing open to be reshaped acc. new improvements depending on BRI. On the fifth stage, Russian trade level is standing with the rate of $3,4 \%$. Very similar to China, Russia is still keeping its socialist roots with a considerable level of protectionism over tariff rates for domestic products. US tariff policy is taking place on 5th level with the rate about $1,6 \%$. US economics and tariff policies had not always proportionated such as ne-liberal approaches. Especially during World War 2 and in short while in afterwards, the rates were higher than the rates today observed.

Nevertheless, during the last quarter of 20th century, the tendency of US economics also drifted to the direction of neo-liberalization and reached the summit after being the member of GATT (Later WTO). Although today's president Donald Trump imposed 10\% tariffs over imported steel products, this rate was removed and pulled down to a convenient level. Canadian economy is as a financial structure, which is being shaped acc. trade relations with the USA as occurring in Mexican economy. In afterwards of World War 2, Canadian market followed up the anti-protectionist tariff policies in collaboration with both the United Kingdom and USA. Nevertheless, the weight of economic tendencies for import products were mostly enjoyed by the British side in the first phase, the transition of advantage from British side ended up at US economics and Canadian economy has been an $\mathrm{m}$ financial structure arranging its tariff rates acc. American relations pose mostly the neo-liberal tendencies. Whereas, Canadian tariff policy on the map can be expressed as the lowest rate compared to other economies today. Concisely, each country and their policies mentioned above had a either slight of quick initiative to remove high tariffs in time, especially their full participation to GATT (WTO). However, while newly released economies like Russia are being able to be undertaken in an easier way because of having experienced an radical change in politics, more unprecedented adaptation to neo-liberal approach by sustaining existing mode of political structure and gaining competitive characteristic in free market, which was mostly dominated by US currency, can be obviously reveal China as pioneer in free market.

\subsection{The trade policy of China}

In a couple of previous decades, China has been driven into a revolutionary transformation and was named as the largest commercial potency, the origin of which widely roots into the institutional reforms and its development strategy. Each step moved forward caused an effective improvement in the new image of China. China joined WTO in 2001 by participating to the local and counter contracts caused a challenging increase for rule and market-oriented trade and liberalization of investment (Bin, 2015: 1-2). Of course the World observing China continued to the restructuring of its economic model in afterwards of taking place among the allies of WTO by the decisions taken under the 18th Central Committee of Chinese Communist Party (CCP) shaped the future plans of further economic reforms, which 
are foreseen as the commercial regulations and concepts, taking regulatory integration under the loop and including a unprecedented size of trade pact (Bin, 2015: 1-2).

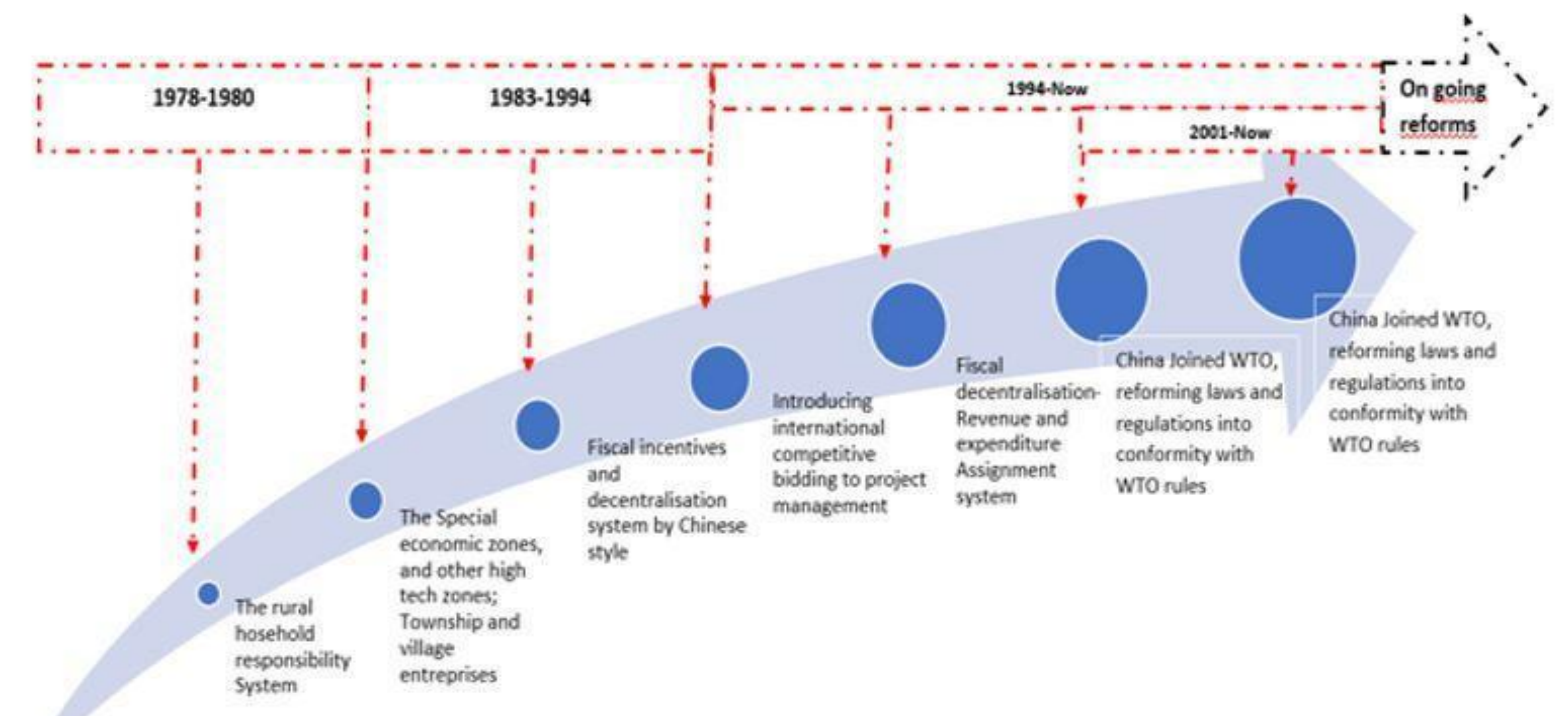

Figure 2. China's integration with the world

Source: Lin \& Wang, 2012

Behind the curtains of the reshaping of the monetary structure of Chinese economy, there are innovative and logic learning based trials lying, which has resulted in micro and macro level of systems reforms. The immediate enlargement and enrichment of Chinese economy had been encouraging for the market-based reforms pushing the most basic instinct of liberalizations by the allowance of leaving doors of commerce open for foreign investment. International trade with in the evolution of market from CAD to CAF paths, led to the awareness of its comparative advantage as a result of reforms compiled through logic of learning and innovative approach (Lin \& Wang, 2012: 7). The influences mentioned brief approach and trials of China were going to be observed in the most basis of commercial activities as import and export by beginning from 1980's after having followed the soviet style of industrialization for 30 years long process until the emerging of import substitution as a focal component for Chinese trade policy until 1990's (Bin, 2015: 2).

The trial of China over import substitution can be defined as the first step of the evolutionary process of Chinese economics as a converting structure to a more openness oriented new order. Before the transition to the new point of view, China was highly interested in heavy industry commodities as a result of import substitution policy as an adverse approach of other far eastern countries shifting their core interest on non-durable high technology goods, pushing the relatively increasing demand. Whereas, the three decades of China passed with economic efficiency by resulting in a financial bottle neck at the end. However, by the alteration of point of view to economics with the radical touch of Mr. Deng Xiaoping, the considerable number of labor-oriented sectors have reached to a exporting position as a outcome of open-door policy (Bin, 2015: 3).

In the next phase of Chinese Liberalization, the changing environment of export entails being handled due to the alteration of tax rates in exporting commodities in downwards. As the interest of Chinese government in the 1980's continued in controlled liberalization in economics, of course the export got its shares from the changing trade policy. This policy and its applications gained the reputation of "protected export promotion", which focuses on 
neutralizing the import subsidies by increasing the percentage of export in economics by keeping the tax barrier over import stable before foreign goods. Whereas the improvement and the growth of exporting sectors supported by the hand of state and other state-controlled institutions kept far away from the intervention of foreign entrepreneurship (Bin, 2015: 3).

During the rising economic power of China in trade contest, a defining policy came in to being with the new broader understanding of much bolder trade liberalization, which includes the decrease in tariff rates, import mandatory plans, import restrictions and other permissions needed by the elimination of duties and substitutions put before both export and import as protective measures. So that the trade liberalization began to gain a wider volume in economic policies of China. Nevertheless, protectionism on trade was still an intense and domination approach, when it was compared with other economies with the average tariff rate of $43 \%$ and the coverage ratio of non-tariff rate was about $51 \%$. While all these were taking place on the stage of Chinese market, the global market was being driven with the low-price competition (Bin, 2015: 4). Of course, the sovereignty of (CCP) Chinese Communist Party kept on feeling its existence over economic policies by introducing their desired concept of "The Socialism Market System with Chinese Characteristics" in 1992 with the purpose of being able to drive a more predictable and desirable structure to follow market focused reforms. In the sense of realization of this concept, the rapprochement with GATT (WTO in 1995) for the integration of Chinese economy to the global world took place with the result of the announcement of Foreign Trade Law for the assessment of more modern and applicable Trade Policy of China in 1994. (Bin, 2015: 4)

Under the continuation phase of WTO rapprochement, the full membership to WTO completed in 2001 and the radical alteration in Chinese monetarial structure sharpened the its concept by issuing the permission for the participation of individual entrepreneurs both from foreign and domestic investment to the game table to cherish the environment of liberalized environment in the border of the frame of "Foreign Trade Law", such a radical trial has been a first transparent model of market economy and trade policies in Chinese region (Bin, 2015: 5). The tariff rates emerged due to radical policies are as revealed below;

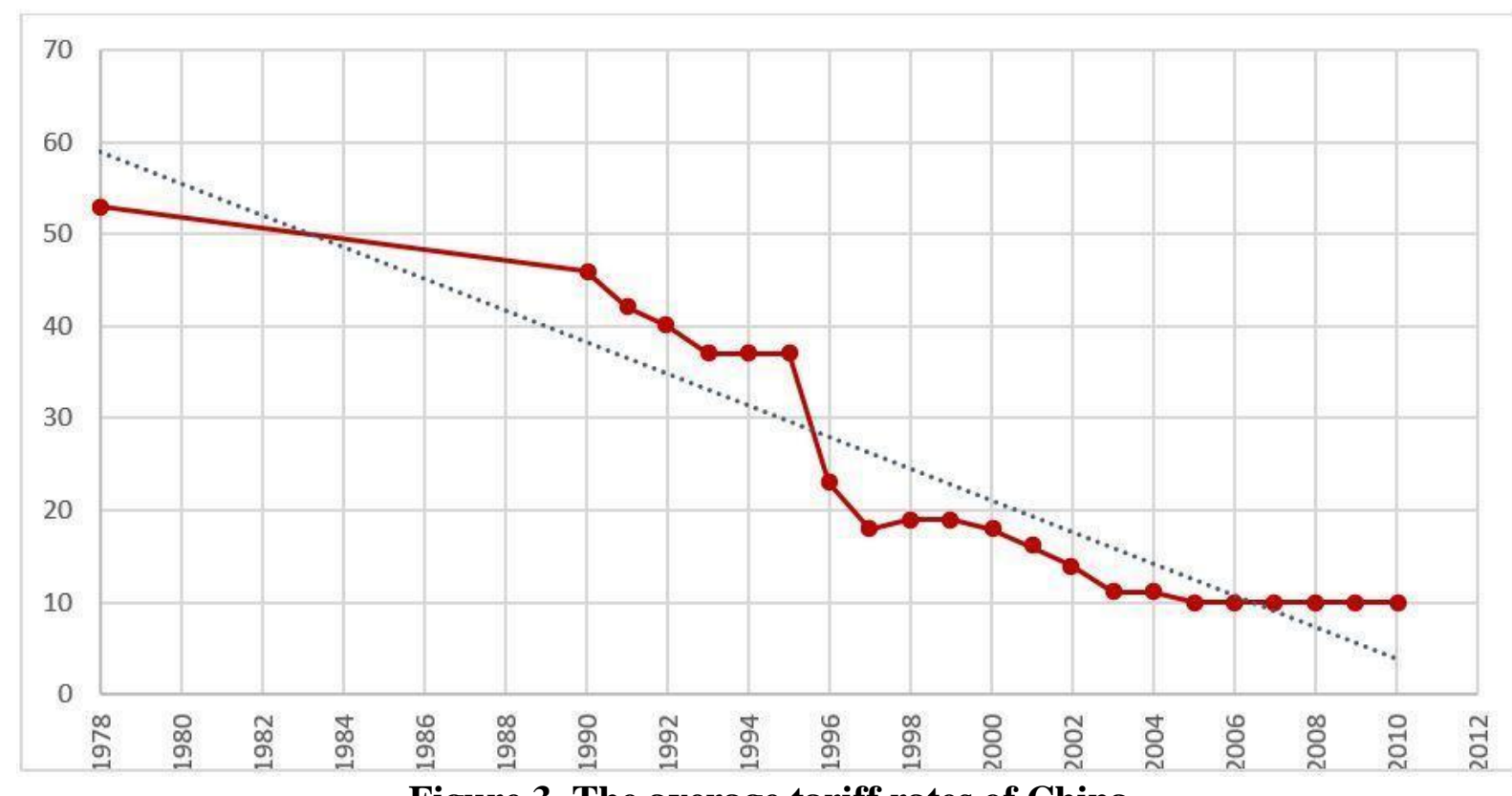

Figure 3. The average tariff rates of China

Source: Li, 2012 
As it is being revealed in the figure above, the liberalized Chinese trade policies and regime produced its outcomes in afterwards of the adaptation to the WTO principles by providing openness to new investment since 1994. Finally, the last declining rate for tariff ratio is being observed with the full membership to the WTO by the application of more free trade being enjoyed by individual entrepreneurs.

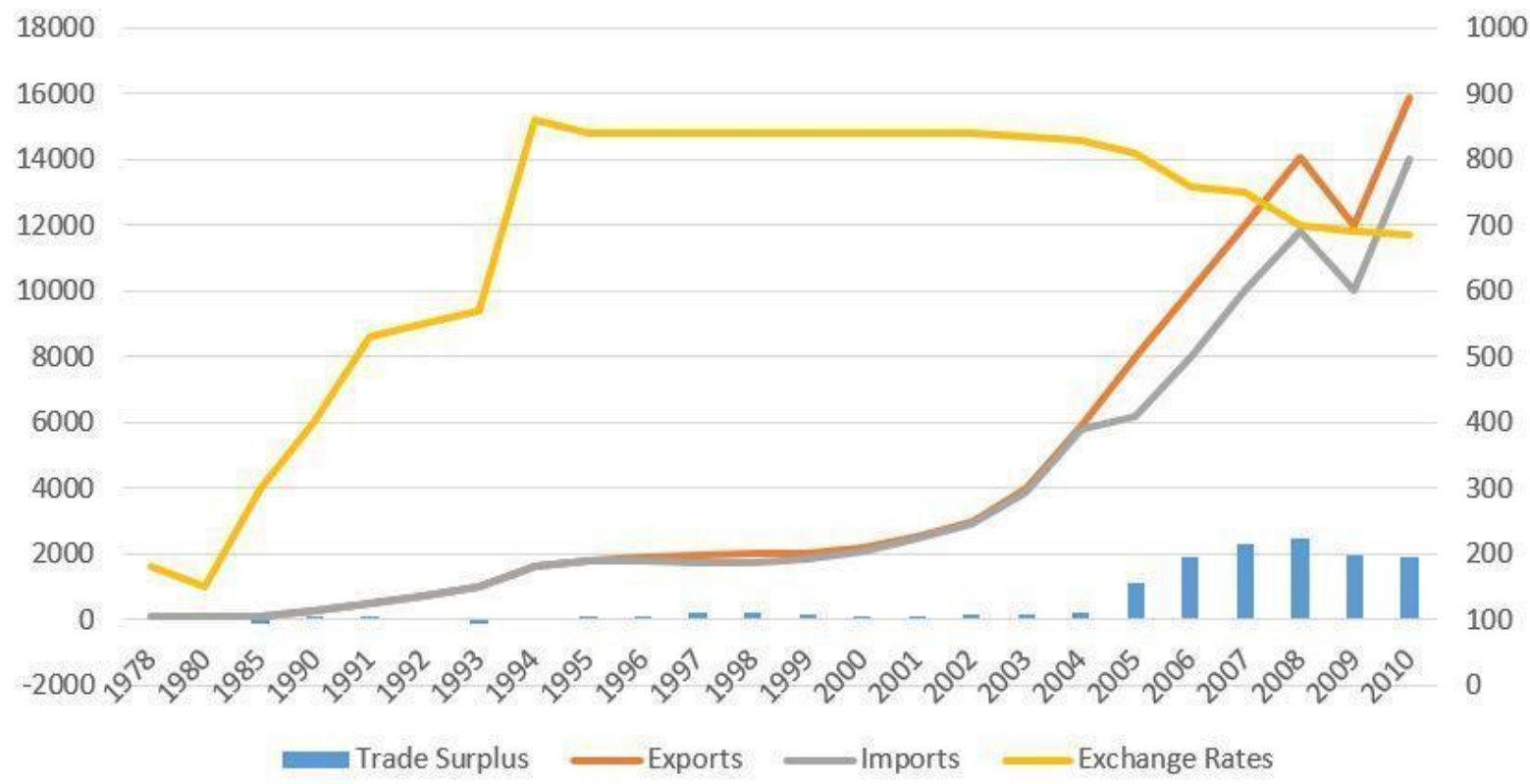

Figure 4. China's trade and exchange rate 1978-2010

Source: Li, 2012

As it is being depicted on the table above, by the acceptance of liberal approach by China the trend of both export and import rates has been driven upwards as result of free trade, allowing the investment both for local individuals and foreign entrepreneurs. Whereas, the decreasing rate of tariffs the annual phase revealed on the first table, had been confirmed as a concrete outcome of the new liberal approach of China to commercial activities. The parallel increase in import and export rates also proves the interest of consumers in different variations of products flowing into the Chinese market and the interest of the World market over Chinese products with cheaper prices. The determining and effective role of tariffs over trade is being visually lied before the eyes of observers, in the sense of defining the transition of exchanges via commodities traded among parties.

As a conclusion, the historical and brief evolution of Chinese economy was tried to be clarified by depending on the chronological timeline. In spite of having summarized the most forth standing events, which had affected the alteration over the monetarily perception of Chinese Communist Party, of course there may be some secondary effects disregarded. Nevertheless, in case of having a clear look over the process, the trials of the government in the sense of providing a controlled openness by supporting the export was being driven as a main policy, as the protectionism over import was sustained with decreasing strictness. In afterwards of participation to WTO with a full membership, the flexibility over import barriers has begun to be experienced and a parallel rise in both import \& export initiated with an upward trend. This openness of China in front of the World Market surely welcomed by some economies because of discovering a new pure field of investments and a certain source for cheap products. Additionally, the financial advantage depending on the cost efficiency attracted the interest of both western and eastern liberals to pay attention. China as an experiencing country in the world trade market today is obviously reaching a new level by 
crowning this success of equilibrium policy in trade with inviting the countries both in far distances and in hinterland to the project of "Belt and Road Initiative". Whereas, the new era of trade wars seems to begin over a new logistic path expected to handle the considerable volume of financial power both in profit of China and participating 64 countries, which may drift away from the domination field of the US economy.

\subsection{The trade policy of USA}

In the post-World War II process, the US economics has devised its policies by basing its approach over the liberalization of the market and acceleration of free trade. As main concern of the liberalizing period, market structure entails being designed through agreements to define the procedure as it took place at fostering an open and non-discriminating rules-based trading system with the World Trade Organization (WTO) (Williams, 2020: 1-2). In addition to the liberalization process, the support provided for trade in the sense of encouragement and arrangement of trade laws for standardization had been the defining milestones for the economic growth with a considerable trend.

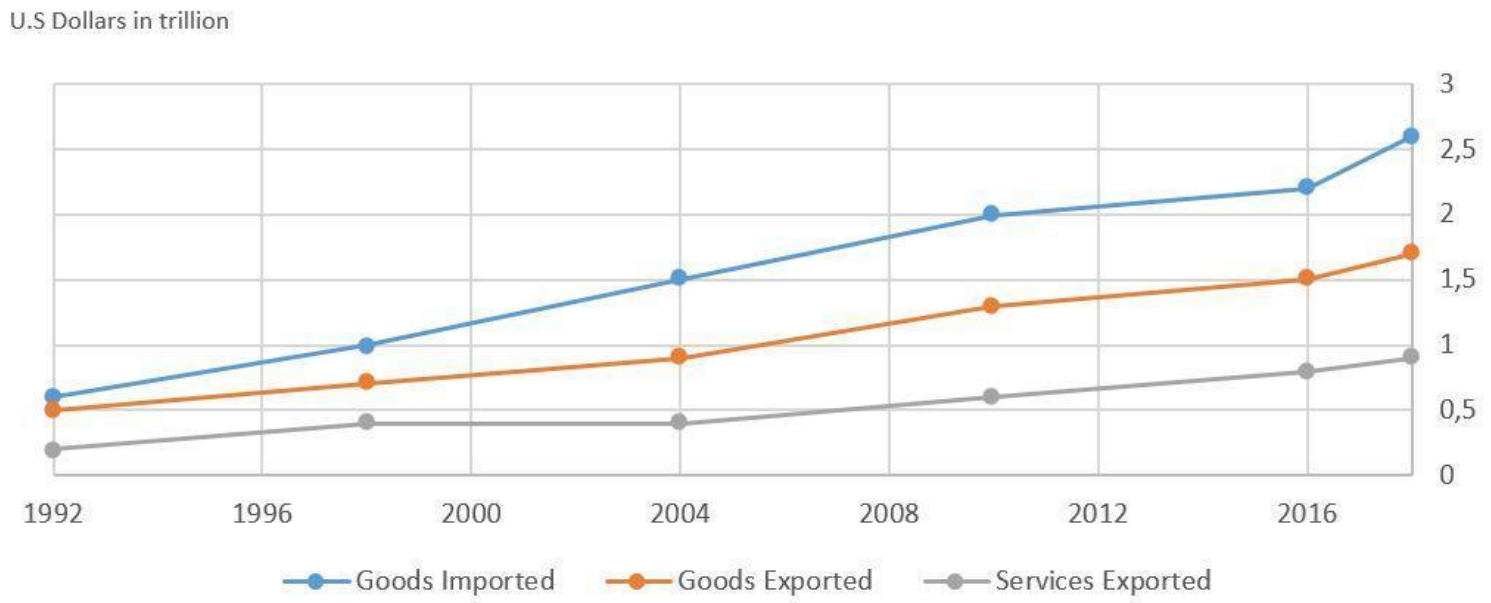

Figure 5. The comparison of export \& import of USA (services and commodities)

Source: Williams, 2020

Of course, the trends in US economics were not continuing as mentioned above. Until the reaching of today's rates and approaches in US economics, the phases accepted as miles stones took place. Today, the US economy is one of the leading economies of the World and the biggest FDI source. The decentralized approach of the US economy to be able to reach each emerging new market by expanding its production to these regions with a convenient proportion provides the full integration for US trade all over the World (Williams, 2020: 1-2). When the graph above is observed, the increased rates of import and export both in services and goods are on a remarkable level by being parallel to the policies applied by the US government in direction of prompting free trade. In spite of all these positive increases in trade activities, the trade deficit of the US economy sustains its existence as a result of a transcending rate of import over export.

The reason for occurrence of this circumstance in economics is being discussed and mostly authorities unites on the point of the rate of types of commodities traded. That clearly means that, the US economy is briefly shifting from being a tangible good economics to intangible good economics with the increasing weight of services traded instead of physical products (Williams, 2020: 1-2). Nevertheless, until reaching to the today's economic volume, the one of the most important point entails being highlighted as a commencement of the tale is Smooth-Hawley tariff act, led to the emerging of tariff over 20000 type of goods and caused 
in decrease in trade volumes regarding American businessmen and farmers on country. Whereas, protectionism in the US economy got the strength as a leading approach to economics (Irwin, 1998).

On the following phase, by being contrary to the protectionism at the beginning, The Reciprocal Trade Agreement came among the rules of game by granting full authorization to the presidency over the adjustment of tariffs through a single hand with other countries. In spite of the continuation of the applications of The Reciprocal Trade Agreement for decades, the most important outcomes of the agreement can be evaluated as the authorization of US president for a first time for the negotiation of tariffs with other countries and mapping of the pre-structure of GATT in advance for the liberalization of trade (Irwin, 1998). In afterwards of The Reciprocal Trade Agreement the initiatives and negotiations brought about both the decrease of tariffs onto considerable level with liberal approach and the emerging of GATT with the participation of 23 countries on purpose of more liberal trade policies may allow the decrease of barriers and increase of volumes in commercial activities in 1947 (Irwin,1998). While entire process had been driving according to liberal map, the concerns of national security about protecting local producers was seen as a stressing effect, In spite of the motivating soul of GATT, rise in rates of tariffs was observed under the reputation of The Trade Expansion Act in 1962 (Knoll,1986). During the thirty-three years long process of liberal experience until 1980, the rates of taxes exposed the policies of US presidents like Nixon and Reagan with the increase of rates in specific range of products as steel and textile as a result of Japanese effects rising from the eastern side. In the following process of all these, NAFTA was established and GATT evolved to another level with a new name called WTO (Knoll, 1986).

Of course, by the participation of China to the WTO the route of publishment of new tariffs or the restructuring of the tariffs took place according to the threatening position of China before US economics. Whereas, the new direction of US economics at defining the tariff level has been determined and the new tariffs were applied by Donald Trump over steel, solar panels, aluminum and machinery products regarding China in 2018 (Amiti \& Mary,2019).

In conclusion, the rise and globalization of US economics had begun in the first quarter of 20th century and tariff policies have been shaped mostly regarding the expansion of trade hegemony all over the world. So that, to keep other countries motivated for trading with low rates of barriers, GATT was shaped in following decades of The Reciprocal Trade Agreement and liberalization gained its speed by the participation of 23 economies under the roof of GATT. In spite of having some obstacles on the way to full liberalization because of national security concerns arising from protectionism, the decline in rates of barriers continued until reaching to the considerable level. However, by the transition of GATT to WTO and the participation of China to this structure, the flow of stream in tariff policies in US economics was begun to be recalculated by observing the threats may emerge from far eastern Asia. Whereas, the launching of new tariffs over critical scopes took its place in US tariff policy and became a warning symptom of an approaching trade war over tariff rates between US and China (Goulard, 2020; Li et al., 2019).

\section{ECONOMETRIC ANALYSIS}

The aim of this study is to analyze the impact of trade wars on countries in the Belt Road Initiative. In this regard, it is going to be demonstrated how trade wars have an impact on exports of countries in the Belt Road Initiative. It is going to be concentrated on the results that will be obtained from commercial cooperation among countries within export potential in the Belt Road Initiative considering trade wars. 


\subsection{Data and methodology}

The paper analyzes the impacts of trade war on countries in the Belt Road Initiative by panel time series models within the context of this study. While exports of countries in the Belt Road Initiative is dependent variable; gross domestic product, population, gross fixed capital, relative factor endowments, simple mean tariff rates on all products of USA and China involved as independent variables in the research models. Datas on countries' in the model covers the period of 2000-2017 and are derived from the database of the World Bank. The information about the variables used in the study is as follows;

$\ln (E X P) \quad:$ Exports of Countries in the Belt Road Initiative

$\ln (G D P) \quad:$ Gross Domestic Product of Countries in the Belt Road Initiative

$\ln (P O P) \quad:$ Population of Countries in the Belt Road Initiative

$\ln (G F C) \quad:$ : Gross Fixed Capital of Countries in the Belt Road Initiative

RELENDOW : Relative Factor Endowments of Countries in the Belt Road Initiative

$\ln ($ TARIFF $) C H N \quad$ : Simple Mean Tariff Rates of China

$\ln ($ TARIFF $)$ USA $\quad$ : Simple Mean Tariff Rates of USA

Gross domestic product and population variables represent the supply and demand of countries in the Belt Road Initiative. In addition, gross fixed capital shows the investment of capital and infrastructure in the Belt Road Initiative countries. Moreover, relative factor endowments of Belt Road Initiative countries stand for trade structure among the countries in the analysis. Furthermore, simple mean tariff rates of China and USA represent the trade war between China and USA in the model. Accordingly, tariff rates of China and USA in the model apply toward the all countries and for all traded goods.

Depending on this information, the dynamic panel data model has been composed to analyze the impact of trade war on exports of countries in the Belt Road Initiative (1);

$$
\begin{aligned}
& \ln \left(E X P_{i, t}\right)=\beta_{0}+\beta_{1} \ln \left(E X P_{(i, t-1)}\right)+\beta_{2} \ln \left(G D P_{i, t}\right)+\beta_{3} \ln \left(P O P_{i, t}\right)+\beta_{4} \\
& \ln \left(G F C_{i, t}\right)+\beta_{5} R E L E N D O W_{i, t}+\beta_{6} \ln \left(T A R I F F_{C H N}\right)_{i, t}+\beta_{7} \ln \left(T_{A R I F F_{U S A}}\right)_{i, t}+\varepsilon_{i, t}(1)
\end{aligned}
$$

Economic decisions generally linked to previous periods and decisions. The lagged impact of the independent variable on the dependent variable should also be taken into account in the analyzes made by considering macroeconomic indicators. Briefly, dynamic panel data models with this impact contain lagged variables.

Many economic relationships in the research could be determined by a static or dynamic process. While panel data analysis can be applied to static processes, it can be applied within the analysis of dynamic processes. There are dynamic panel data models developed for this purpose. A dynamic panel data model, including the lagged value of the dependent variable, can be written as follows (2);

$y_{i t}=\theta y_{i, t-1}+\beta x_{i t}^{\prime}+c_{i}+\varepsilon_{i t}$

The lagged value of the dependent variable included in the model is associated with the combined error term $\delta_{i t}=c_{i}+\varepsilon_{i t}$. The main reason for this situation is that $c_{i}$, which expresses the heterogeneity specific to the cross sections, is the same for each observation of each group. The popular method used in the literature is the Generalized Moments Method (GMM) estimators developed by Arellano and Bond (1991) and Arellano and Bover (1995) (Greene, 2012: 497). 
The values of $\left(y_{i t-2}, y_{i t-3}, \ldots, y_{i t-n}\right)$ considered as lagged variables, these lagged values are the instrument variables suitable for the model since the correlation with the previous difference error term is zero. The instrument variable matrix is expressed as follows (3);

$z_{i}=\left[\begin{array}{ccccccc}y_{i 1} & 0 & 0 & 0 & 0 & 0 & \vdots \\ 0 & y_{i 2} & y_{i 1} & 0 & 0 & 0 & \vdots \\ 0 & 0 & 0 & y_{i 3} & y_{i 2} & y_{i 1} & \vdots \\ \vdots & \vdots & \vdots & \vdots & \vdots & \vdots & \ddots\end{array}\right]$

In order to reduce the trouble of endogeneity with explanatory variables, Arellano and Bond (1991) offer the use of instrumental variables to find out the generalized method of moments (GMM) of suitable moment conditions, namely difference GMM. The main idea of the method is to rule out the individual fixed effect by proceeding with the first difference of the regression equation in the first place. Then, the lagged variable will be assumed as the corresponding instrumental variable of endogenous variables in the difference equation (Bond et al., 2001). Arellano and Bover (1995) and Blundell and Bond (1998) offer a solution to this trouble, enabling a "system-GMM" estimator in which GMM is applied to a system of two equations. These two equations are an equation in differences instrumented by lagged levels and an equation in levels instrumented by lagged differences. GMM model is as follows (4); $\theta_{G M M}=\left(\Delta x^{\prime} \mathrm{z}\left(\mathrm{z}^{\prime} \Omega \mathrm{z}\right)^{-1} \mathrm{z}^{\prime} \Delta x\right)^{-1}\left(\Delta x^{\prime} \mathrm{z}\left(\mathrm{z}^{\prime} \Omega \mathrm{z}\right)^{-1} \mathrm{z}^{\prime} \Delta y\right)$

Dumitrescu-Hurlin (2012) panel causality test analyzes the causal relationships among the variables. Dumitrescu-Hurlin (2012) panel causality test examine hypothesis cannot reject the causality relationship in at least one cross-section against the absence of the homogeneity of Granger causality relationship considering the cross-sectional dependence among the countries. Accordingly, Dumitrescu-Hurlin (2012) panel causality test gives the effective results under the larger or smaller size of time series and cross-section conditions. Dumitrescu-Hurlin (2012) panel causality model is as follows (5);

$Y_{i, t}=a_{i}+\sum_{k=1}^{k} Y_{i}^{(k)} Y_{i, t-k}+\sum_{k=1}^{k} \beta_{i}^{(k)} X_{i, t-k}+e_{i, t}$

The equation is used to check whether the $\mathrm{x}$ variable is the cause of the $\mathrm{y}$ variable, and this causality relationship is tested using the $\mathrm{h}_{0}$ hypothesis on the basis of an $\mathrm{F}$ test. However, if the $\mathrm{h}_{0}$ hypothesis is rejected, a bidirectional causality relationship can be observed by changing the direction of causality via displacing the variables (Lopez \& Weber, 2017: 2).

\subsection{Empirical results}

Research hypothesis of the paper is that trade war between China and USA has affected exports of countries in the Belt Road Initiative negatively. The impact of trade war on the exports of countries in the Belt Road Initiative will be investigated by the panel data analyses but initially, it is required to examine the stationary of the panel data series.

To be able to analyze the variables in panel data series, the variables must be stationary. In this direction, stationary levels of variables should be determined. Variables in the panel data analysis have been examined with panel unit root test developed by Levin, Lin and Chu (2002). As can be seen in Table 1, all of the variables [I(0)] in the level values are stationary. The model specified previously (see Eq. (1)) ensures to analyze the effect of our two core variables on the export of countries in the Belt Road Initiative: trade wars of China-USA, measured by the mean tariff rates of China and USA. The estimation also includes a set of control variables related to gross domestic product, population, gross fixed capital and relative factor endowments, which the empirical literature identifies as relevant factors of export. 
Table 1. Levin, Lin and Chu (2002) panel unit root test

\begin{tabular}{|c|c|c|}
\hline Variables & $\mathrm{C}$ & $\mathrm{C}+\mathrm{T}$ \\
\hline $\ln (E X P)$ & $-6.231 * * *$ & $-4.701 * * *$ \\
\hline $\ln (G D P)$ & $-2.606^{* * *}$ & $-5.898 * * *$ \\
\hline $\ln (P O P)$ & $-2.909 * * *$ & $-15.407 * * *$ \\
\hline $\ln (G F C)$ & $-1.755^{* *}$ & $-5.393 * * *$ \\
\hline RELENDOW & $-4.742 * * *$ & $-3.242 * * *$ \\
\hline $\ln (\text { TARIFF })_{C H N}$ & $-46.022 * * *$ & $-29.704 * * *$ \\
\hline $\ln (T A R I F F)_{U S A}$ & $-6.459 * * *$ & $-2.149 * *$ \\
\hline
\end{tabular}

Notes: "C" stands for constant term, "I + T" represents constant and trend. Lag lengths are chosen according to the T statistics. $*^{* *}, * *$, and $*$ indicate significance at $1 \%, 5 \%$ and $10 \%$ respectively. All results at first differences are stationary at $1 \%$ significance level.

Table 2 demonstrates the dynamic panel data estimation for coefficients corresponding to each variable for both considered panels. Analysis results has been presented by using Arellano-Bond (1991) and Arellano-Bover (1995) GMM estimators, which are frequently used and popular in the dynamic panel literature. The empirical results of the system GMM estimation is acceptable, satisfactory and robust in this study.

Table 2. Results of dynamic panel data analysis

\begin{tabular}{|c|c|c|c|c|c|c|c|c|}
\hline \multirow[t]{2}{*}{ Variables } & \multicolumn{4}{|c|}{$\begin{array}{c}\text { Arellano-Bond } \\
\text { Dynamic Panel Data Estimation }\end{array}$} & \multicolumn{4}{|c|}{$\begin{array}{l}\text { Arellano-Bover/Blundell-Bond } \\
\text { Dynamic Panel Data Estimation }\end{array}$} \\
\hline & \multicolumn{8}{|c|}{ Coefficients } \\
\hline $\ln \left(E X P_{(t-1)}\right)$ & $0.67 * * *$ & $0.65 * * *$ & $0.66^{* * *}$ & $0.66^{* * *}$ & $0.76^{* * *}$ & $0.76 * * *$ & $0.76^{* * *}$ & $0.76^{* * *}$ \\
\hline $\ln (G D P)$ & $0.69 * * *$ & $0.69 * * *$ & $0.70 * * *$ & $0.69 * * *$ & $0.29 * * *$ & $0.29 * * *$ & $0.29 * * *$ & $0.29 * * *$ \\
\hline $\ln (P O P)$ & $-0.33 * * *$ & $-0.31 * * *$ & $-0.33 * * *$ & $-0.31 * * *$ & $-0.06 * * *$ & -0.02 & $-0.04 *$ & -0.02 \\
\hline $\ln (G F C)$ & $-0.05 * *$ & $-0.06 * * *$ & $-0.053 * *$ & $-0.06 * * *$ & 0.01 & $-0.03 *$ & -0.01 & $-0.03 * *$ \\
\hline RELENDOW & $-0.05^{* *}$ & $-0.07 * * *$ & $-0.053 * *$ & $-0.06 * * *$ & 0.01 & $-0.03 *$ & -0.01 & $-0.03 * *$ \\
\hline $\ln (T A R I F F)_{C H N}$ & - & $-0.08 * *$ & - & $-0.14 * *$ & - & $-0.13 * * *$ & - & $-0.19 * * *$ \\
\hline $\ln (T A R I F F)_{U S A}$ & - & - & -0.03 & 0.12 & - & - & $-0.09 *$ & 0.13 \\
\hline $\mathbf{C}$ & $-2.83 * *$ & $-2.25 * *$ & $-2.76 * *$ & $-2.27 * *$ & -0.68 & -0.26 & -0.46 & -0.34 \\
\hline Tests & \multicolumn{8}{|c|}{ Diagnostic Tests Results } \\
\hline Wald Chi ${ }^{2}$ & $\begin{array}{c}10432.1 \\
(0.000)\end{array}$ & $\begin{array}{c}10463.7 \\
(0.000)\end{array}$ & $\begin{array}{c}10418.5 \\
(0.000)\end{array}$ & $\begin{array}{c}10392.6 \\
(0.000)\end{array}$ & $\begin{array}{c}15569.8 \\
(0.000)\end{array}$ & $\begin{array}{c}15342.5 \\
(0.000)\end{array}$ & $\begin{array}{c}15409.4 \\
(0.000)\end{array}$ & $\begin{array}{c}15276.2 \\
(0.000)\end{array}$ \\
\hline Sargan Test & $\begin{array}{c}435.3 \\
(0.000)\end{array}$ & $\begin{array}{c}440.8 \\
(0.000)\end{array}$ & $\begin{array}{c}434.4 \\
(0.000)\end{array}$ & $\begin{array}{c}434.9 \\
(0.000)\end{array}$ & $\begin{array}{c}591.4 \\
(0.000)\end{array}$ & $\begin{array}{c}578.4 \\
(0.000)\end{array}$ & $\begin{array}{c}582.6 \\
(0.000)\end{array}$ & $\begin{array}{c}573.2 \\
(0.000)\end{array}$ \\
\hline
\end{tabular}

Notes: $* * *, * *$, and $*$ indicate significance at $1 \%, 5 \%$ and $10 \%$ respectively. All results at first differences are stationary at $1 \%$ significance level.

The lagged value of dependent variable is statistically significant and positive. This result show that one lagged exports of countries in the Belt Road Initiative has positive effect on exports of countries in the next period. In other words, there are dynamic impacts on exports of Belt Road countries. Moreover, it is seen that gross fixed capital and population of these countries has negative impacts on their export volumes. In this direction, it is predicted that this countries will be more successful and they will have positive effects on exports as long as the Belt and Road countries take the right measures and make the right investments.

The gross domestic product shows a significant positive impact in both models and suggests as accepted in the literature, that countries with a higher production capacity exports more in the considered periods. In addition, it is seen that the coefficient of factor endowment variable of the Belt Road countries is negative; therefore, it shows an intra-industry trade structure. 
The effect of tariff rates of China, which is one of the main variables of the model, is statistically significant and negative on the export of Belt Road countries. According to the results, the increase in tariff rates of China within the scope of trade wars causes the export of Belt Road countries. Contrary to this situation, it has been revealed that increase of the tariff rates of the USA does not have a statistically significant effect on the export of Belt Road countries. The results show that trade wars have negative effects on Belt Road countries. Especially, the increments of China's tariff rates reduce exports of Belt Road countries. Furthermore, the results support that the Belt Road initiative is composed of countries in China's influence area.

Table 3. Dumitrescu-Hurlin causality test results

\begin{tabular}{|c|c|c|}
\hline Causality Relationship & $\begin{array}{c}Z^{H N C} \\
N, T\end{array}$ & $\begin{array}{c}Z^{H N C} \\
N\end{array}$ \\
\hline $\ln (T A R I F F)_{C H N}=>\ln (E X P)$ & $15.64 * * *$ & $6.53 * * *$ \\
\hline $\ln (E X P)=>\ln (T A R I F F)_{C H N}$ & 1.26 & 0.39 \\
\hline $\ln (T A R I F F)_{U S A}=>\ln (E X P)$ & $15.04 * * *$ & $10.75^{* * *}$ \\
\hline $\ln (E X P)=>\ln (T A R I F F)_{U S A}$ & -0.82 & -1.18 \\
\hline
\end{tabular}

Notes: $* * *, * *$, and $*$ indicate significance at $1 \%, 5 \%$ and $10 \%$ respectively. Lag lengths are determined by Akaike Information Criteria.

Causality relationships among the variables are given by Table 3. According to the results of Dumitrescu-Hurlin (2012) causality test, it is determined that there are unidirectional causality relationships from tariff rates of China and USA to exports of the Belt and Road countries. These results demonstrate that the increase in the tariff rates of China and US in accordance with the trade wars have affected the export volume of the Belt and Road countries.

\section{CONCLUSION}

The Belt Road project, which is called the modern Silk Road, aims to increase the international trade volume, has been introduced by China as of 2013. Along with the Belt Road project, it is aimed that the countries in the project facilitate international trade between each other and thus revive the international trade route between East and West.

In this paper, the impacts of trade wars on countries in the Belt Road Initiative have been analyzed. The paper also examines the effects of GDP, population, gross fixed capital investments and factor endowments of the Belt Road countries in terms of export performance. As long as the US and China increase the tariff rates in international trade, it is estimated that the Belt Road countries are affected by trade wars between the US and China. Accordingly, the study contributes to theoretical and empirical literature of international trade by virtue of proving the effects of trade wars and tariff rates on the Belt Road countries.

The relations among exports, GDP, population, gross fixed capital investments and factor endowments of the Belt Road countries is analyzed by using Arellano-Bond (1991) and Arellano-Bover (1995) GMM estimators in the study. Arellano-Bond (1991) and ArellanoBover (1995) GMM estimators allow estimating the dynamic relationship among the variables. In addition to this, causality relationship among the variables is examined via Dumitrescu-Hurlin panel causality methods in the paper. These empirical methods enhance new perspectives to investigate effects of trade wars on the Belt Road countries.

At first, dynamic panel data analysis is performed in order to demonstrate the dynamic relations among the variables. According to the results of the tests, it is approved that there are statistically significant impacts of trade wars on the exports of the Belt Road countries. In 
regards to results of dynamic panel data analysis, the increase in tariff rates of China has led to decrease of exports of the Belt Road countries. On the other hand, the increment in tariff rates of the US have not affected statistically to exports of the Belt Road countries. In addition, the results show that the increment in both one lagged value of export and GDP positively affect the export volume of the Belt Road countries. Moreover, the increasing population, gross fixed capital investments and factor endowments in the Belt Road countries have negative impacts on their exports. Thus, it is concluded that negative effects of increments of tariff rates in China on the Belt Road countries are more crucial than changes of tariff rates of the US in trade wars. Thereby, these results support the hypothesis that China's international trade policies are more effective on the Belt Road countries than US trade policies in trade wars.

According to results of Dumitrescu-Hurlin panel causality analysis, there is a unidirectional causality relationship from tariff rates of China and US to exports of the Belt Road countries. In this context, it is revealed that trade wars between China and the US affect exports of the Belt Road countries. More clearly, it is seen that the rise of violence of trade wars have been caused to decline in export volume of the Belt Road countries. As a result of the analysis, it is observed that the negative steps taken by China especially within the trade wars have negative effects on export volume of Belt and Road countries. According to the empirical evidence of this paper, it reveals that China has chosen the countries to be included in the Belt and Road project from among the countries within its sphere of influence and those important commercial relations have been established with these countries. In this direction, China's adoption of an international trade policy that avoids the negative effects of trade wars is substantial for the success of the Belt and Road project.

\section{REFERENCES}

Amiti, M., Stephen J.R. \& Weinstein, D.E. (2019). The impact of the 2018 tariffs on prices and welfare. The Journal of Economic Perspectives, 33(4), 187-210.

Arellano, M. \& Bond, S. (1991). Some tests specification for panel data: Monte Carlo evidence and an application to employment equations. The Review of Economic Studies, 58(2), 277-297.

Arellano, M. \& Bover, O. (1995). Another look at the instrumental variable estimation of error-components models. Journal of Econometrics, 68, 29-51.

Bin, S. (2015) China's trade development strategy and trade policy reforms: Overview and prospect. Retrieved October 22, 2019, from https://www.iisd.org/system/files/ publications/china-trade-strategy-policy-reform.pdf.

Blundell, R. \& Bond, S. (1998). Initial conditions and moment restrictions in dynamic paneldata models. Journal of Econometrics, 87(1), 115-143.

Bond, S., Hoeffler, A. \& Temple, J. (2001). GMM estimation of empirical growth models. C.E.P.R. Discussion Papers, No. 3048. University of Bristol, Bristol, UK.

Chang, H.J. (2007). The bad samaritans: The myth of free trade and the secret history of capitalism. USA: Boloomsbury Press.

Chen, A. W., Chen, J. \& Dondeti, V. R. (2020). The US-China trade war: Dominance of trade or technology? Applied Economics Letters, 27(11), 904-909.

Chen, Y. \& Hodzi, O. (2017). The Great Rejuvenation? China's Search for a New 'Global Order'. Institute for Security \& Development Policy, Asia Paper. Retrieved October 10, 2019, from http://isdp.eu/publication/china-new-global-order-institutions/.

Dülfer (2005). Episoden des Logistik-Managements in Antike und Mittelalter. In: Logistik Stories | Göpfert / Froschmayer (Hrsg.) 
Dumitrecsu, E.I., \& Hurlin, C. (2012). Testing for Granger non-causality in heterogeneous panels. Economic Modelling, 29(4), 1450-1460.

Githaiga, N.M., Burimaso, A., Bing, W. \& Ahmed, S.M. (2019). The Belt and Road Initiative opportunities and risks for Africa's connectivity. China Quarterly of International Strategic Studies, 5(1), 117-141.

Goulard, S. (2020). The impact of the US-China trade war on the European Union. Global Journal of Emerging Market Economies, 1-13.

Greene, W. (2012). Econometric analysis. USA: Pearson Education Publication.

Irwin, D. A. (1998). The smooth-hawley tarrif: a quantitative assesment. The Review of Economics and Statistics, 80(2), 326-334.

Kelly, B., Jinjun, X., Larry, L. \& Qian, S. (2020). The indirect economic and environmental effects of China's Belt and Road Initiative. The Economic Science, 4(3), 10-26.

Knoll, D.D. (1986). Section 232 of the trade expansion act of 1962: Industrial fasteners, machine tools and beyond, Journal of International Law \& Trade, 10, 55-88.

Levin, A., Lin, C.F. \& Chu, C.J. (2002). Unit roots tests in panel data: Asymptotic and finitesample properties. Journal of Econometrics, 108(1), 1-24.

Li, M., Balistreri, E.J. \& Zhang, W. (2019). The U.S.-China trade war: Tariff data and general equilibrium analysis. Journal of Asian Economics, 69, 1-13.

Li, X. (2012). China's geoeconomic strategy: China as a trading superpower. IDEAS reports special reports, In N. Kitchen (Ed.), China's geoeconomic strategy (pp.25-31). London, UK: LSE IDEAS.

Lin, J.Y. \& Wang, Y. (2012). China's integration with the world: development as a process of learning and industrial upgrading. China Economic Policy Review, 1(1), 1-33.

Lopez, L. \& Weber, S. (2017). Testing for Granger causality in panel data. University of Neuchatel Institute of Economic Research, IRENE Working paper 17-03, 1-12.

McCarthy, N. (2018, March 23). Where tariffs are highest and lowest around the world. Forbes. Retrieved November 19, 2019, from https://www.forbes.com/sites/niallmccarthy/ 2018/03/23/where-global-tariffs-are-highest-and-lowest-infographic/.

Mexico - Trade and Economic Overview (2015). Retrieved December 19, 2019, from https://www.flandersinvestmentandtrade.com/export/sites/trade/files/news/660150618171 409/660150618171409_2.pdf.

Napang, M., Nurhasanah, S. \& Rohman, S. (2019). One Belt One Road (OBOR) and the increase of China's global influence. International Journal of Social Sciences, 5(2), 53-69.

Passi, R., Keough, J., Roy, M.S., Yu, H., Kassenova, N., Small, A., et al. (2017). China's Belt and Road Initiative: Views from along the Silk Road. The National Beurau of Asian Research. Retrieved November 13, 2019, from: https://www.nbr.org/publication/chinasbelt-and-road-initiative-views-from-along-the-silk-road/

Sharma, A. (2019). An analysis of 'Belt and Road' initiative and the Middle East. Asian Journal of Middle Eastern and Islamic Studies, 13(1), 35-49.

Singh, H.V. (2017). Working paper: Trade policy reform in india since 1991. Retrieved December 21, 2019, from https://www.brookings.edu/research/working-paper-tradepolicy-reform-in-india-since-1991/.

Williams, B.R. (2020). U.S. Trade Policy: Background and Current Issues. Congressional Research Service. Retrieved September 15, 2020, from: https://fas.org/sgp/crs/ row/IF10156.pdf

Zhao, S. (2020). China's Belt-Road Initiative as the Signature of President Xi Jinping Diplomacy: Easier said than done. Journal of Contemporary China, 29(123), 319-335. 